\title{
STUDI KEPEDULIAN MASYARAKAT SLEMAN MEMBANGUN SUMUR RESAPAN AIR HUJAN
}

\author{
Oleh: \\ Suhadi Purwantoro \\ Jurusan Pendidikan Geografi, FISE UNY
}

\begin{abstract}
Abstrak
Penelitian di sebagian wilayah lereng Merapi bagian selatan yang diwakili Kecamatan Pakem dan Kecamatan Ngemplak bertujuan untuk mengetahui tingkat pengetahuan masyarakat tentang sumur resapan air hujan dan mengetahui tingkat kepedulian masyarakat tentang sumur resapan air hujan. Dalam hal ini wilayah lereng Gunung Merapi bagian selatan merupakan wllayah resapan air hujan yang menjadi penyangga konservasi air tanah dl Kota Yogyakarta. Populasi dalam penelitian adalah semua masyarakat Sleman yang membangun rumah dalam periode 10 tahun terakhir. Penelitian ini bersifat penelitian deskriptif berdasarkan hasii wawancara pendapat masyarakat.

Hasil penelitian menunjukkan bahwa sebagian besar masyarakat Sleman yang ada di Kecamatan Pakem dan Ngemplak yang menjadi responden sudah tahu manfaat sumur resapan air hujan untuk menghindari banjir (82,15\%), walaupun sebagian besar tidak tahu manfaatnya untuk konsenasi air tanah (60,72\%). Sebagian besar responden tidak memiliki resapan air hujan $(89,29 \%)$ dan sebagian besar responden juga tidak akan membangun sumur resapan air hujan $(67,86 \%)$. Ketidakpedulian masyarakat membangun sumur resapan air hujan tersebut karena sebagian besar lingkungan permukimannya sudah tersedia saluran drainase.
\end{abstract}

Kata kunci: kepedulian masyarakat, sumur resapan

\section{Pendahuluan}

Krisis air di Pulau Jawa akan segera terjadi apabila tidak ada ketegasan pemerintah dalam pengelolaan air. Kekhawatiran tentang krisis 
|| Studi Kepedulian Masyarakat Sleman Membangun Sumur Resapan Air Hujan

air dapat terselesaikan apabila pemerintah bersama masyarakat segera memberlakukan peraturan secara konsekuen tentang resapan air hujan. Kawasan resapan air yaitu wilayah yang dapat meresapkan air hujan ke dalam tanah sebagai penyedia air tanah pada daerah bawahannya. Kawasan resapan air merupakan tempat pengisian air bumi (akuifer) yang berguna sebagai sumber air (Keppres No 32 tahun 1990). Pengertian lainnya, kawasan resapan air atau disebut sebagai daerah tangkapan air secara lebih spesifik didefinisikan sebagai bagian dari suatu daerah aliran (watershed/catchment area) di mana aliran air tanah yang saturated menjauhi muka air tanah (Kodoatie, 1996: 10).

Di kota-kota besar seperti Bandung, Jakarta, Semarang, dan Surabaya, sudah menjadi kenyataan masyarakat kesulitan mendapatkan air bersih. Air bersih yang sebagian besar berasal dari air tanah melalui mata air dan sumur semakin kecil debitnya. Hal itu terjadi karena semakin bertambahnya jumlah penduduk dan berkurangnya areal resapan air hujan.

Sebenarnya resapan air hujan alami dapat berupa hutan yang ada di daerah tangkapan air hujan di suatu pulau. Idealnya jumlah hutan di suatu pulau adalah seluas 30\% dari luasnya. Di Pulau Jawa' jumlah hutan yang ada sekarang diperkirakan tinggal belasan persen. Dengan kenyataan itu maka salah satu alternatif penanggulangan krisis air dalam jangka pendek adalah pembangunan sumur resapan air hujan.

Resapan air hujan berfungsi memasukkan air hujan langsung ke tubuh air tanah. Dengan demikian maka air tanah selalu terjaga fungsi dan kelestariannya. Di lain pihak air hujan tidak perlu menjadi air limpasan (run-off). Air hujan, juga tidak akan mienjadi sumber banjir bandang. Semakin dalam sumur penduduk yang ada di perkotaan semakin sering banjir yang terjadi di wilayah dataran rendah, merupakan ketidakseriusan pemerintah bersama masyarakat dalam mengelola air.

Pemerintah Daerah Istimewa Yogyakarta tidak perlu berencana mengimpor air dari luar daerah, Magelang, apabila Pemda segera mewajibkan kepada setiap rumah tangga membangun sumur resapan. Demikian pula masyarakat tidak perlu khawatir dengan banjir lokal pada musim penghujan apabila ada kewajiban masyarakat membangun sumur resapan air hujan. 
Berkaitan dengan latar belakang permasalahan tersebut, maka diteliti mengenai kepedulian masyarakat terhadap pembangunan sumur resapan air hujan di Sleman.

\section{Metode Penelitian}

Lokasi dalam penelitian ini adalah sebagian wilayah lereng Merapi bagian selatan yang diwakili dua kecamatan, yaitu Kecamatan Pakem dan Kecamatan Ngemplak. Lereng Merapi bagian selatan sebagai wilayah penelitian dikatakan sebagai kawasan resapan air, karena telah memenuhi semua persyaratan dari kawasan lindung (Asdak, 1995). Wilayah Kecamatan Pakem, berjarak $17 \mathrm{~km}$ dari pusat Kota Yogyakarta. Wilayah lainnya dalam penelitian ini adalah Kecamatan Ngemplak, yang berjarak kurang rebih $20 \mathrm{~km}$ dari pusat Kota Yogyakarta. Wilayah Pakem dan Ngemplak, wilayah inilah yang digeneralisir mewakili Kabupaten Sleman. Populasi dalam penelitian ini adalah semua masyarakat Sleman yang membangun rumiah dalam periode 10 tahun terakhir. Penelitian ini bersifat penelitian deskriptif berdasarkan hasil wawancara pendapat masyarakat. Penelitian deskriptif yaitu suatu penelitian untuk memperoleh suatu keterangan yang jelas dan baik terhadap suatu persoalan pada suatu daerah atau kondisi obyek yang diteliti pada saat dilakukan penelitian.

Pendekatan Geografi yang digunakan dalam penelitian ini adalah pendekatan ekologi. Pendekatan ekologi merupakan pendekatan yang menekankan pada lingkungan hidup dan interaksinya dengan manusia. Dalam hal ini wilayah lereng Gunung Merapi bagian selatan merupakan wilayah resapan air hujan yang menjadi penyangga konservasi air tanah di Kota Yogyakarta.

Masyarakat yang dijadikan sampel kepedulian pembangunan sumur resapan air hujan adalah wilayah lereng Merapi bagian selatan. Di dalam penelitian ini terdiri dari dua kecamatan yaitu Kecamatan Pakem dan Kecamatan Ngemplak. Pertimbangan pengambilan sampel di wilayah tersebut karena pertimbangan bahwa kedua wilayah tersebut merupakan wilayah lereng tengah dan atas yang efektif untuk wilayah resapan air hujan, sementara saat ini banyak dikembangkan menjadi permukiman baru, rumah peristirahatan, kampus-kampus, bahkan pusat pelatihan dan perkantoran.

Penelitian ini menggunakan instrumen penelitian berupa panduan wawancara yang disesuaikan dengan pertanyaan penelitian. Untuk 
mencapai tujuan penelitian maka data yang dikumpulkan dibagi menjadi dua yaitu data primer dan data sekunder. Data primer atau data tangan pertama adalah data yang diperoleh secara langsung dari subjek penelitian dengan menggunakan panduan wawancara. Data primer didapat dari hasil wawancara langsung masyarakat pembangun rumah dalam periode 10 tahun terakhir, dengan purposive random sampling. Sampel diambil wilayah Pakem dan Ngemplak, dengan alasan wilayah itu banyak tumbuh permukiman baru, termasuk gedung perkantoran dan kampus. Alasan lainnya, wilayah itu tepat berada di atas atau utara wilayah urban Yogyakarta. Pengumpulan data sekunder diperoleh dari instansi-instansi yang terkait dengan masalah dan tujuan penelitian antara lain: monografi kecamatan, peta jenis tanah, peta kemiringan lereng, peta dasar dan lain sebagainya.

Dalam penelitian ini analisis dilakukan pada hasil wawancara berupa pengetahuan dan kepedulian masyarakat dalam hal sumur resapan air hujan. Hasilnya dilaporkan dalam bentuk deskripsi hasil penelitian.

\section{Hasil Penelitian dan Pembahasan}

1. Lokasi

Lokasi penelitian meliputi 2 wilayah kecarnatan, yang merupakan bagian dari wilayah Kabupaten Sleman, yaitu Kecamatan Ngemplak dan Pakern.

a. Kecamatan Ngemplak

Kecamatan Ngemplak, terletak di sebelah selatan Kecamatan Pakem. Secara astronomis, terletak antara $7^{\circ} 37^{\prime} 19^{\prime \prime}$ $7^{\circ} 45^{\prime} 37^{\prime \prime}$ dan antara $110^{\circ} 22^{\prime} 32^{\prime \prime}$ - $110^{\circ} 25^{\prime} 31^{\prime \prime}$ dengan tinggi tempat antara 150 - $450 \mathrm{~m}$ di atas permukaan air laut (berdasar pelacakan dengan Google Earth).

Secara administratif, Kecamatan Ngemplak memiliki batasbatas wilayah sebagai berikut: Sebelah Utara kecamatan berbatasan dengan Kecamatan Pakem dan' Cangkringan, Sebelah Timur kecamatan berbatasan dengan Kabupaten Klaten Propinsi Jawa Tengah, Sebelah Selatan kecamatan berbatasan dengan Kecamatan Ngaglik, Depok, dan Prambanan Sleman, Sebelah Barat kecamatan berbatasan dengan Kecamatan Ngaglik dan Pakem.

b. Kecamatan Pakem 
Kecamatan Pakem terletak di sebelah selatan lereng Gunungapi Merapi. Secara astronomis terletak antara $7^{\circ} 32^{\prime} 30^{\prime \prime}$ $7^{\circ} 42^{\prime} 00^{\prime \prime} \mathrm{LS}$ dan $110^{\circ} 22^{\prime} 30^{\prime \prime}-110^{\circ} 27^{\prime} 30^{\prime \prime} \mathrm{BT}$ dengan tinggi tempat antara $300 \mathrm{~m}-2.900 \mathrm{~m}$ di atas permukaan laut.

Secara administratif, Kecamatan Pakem mempunyai batasbatas sebagai berikut: Sebelah utara kecamatan berbatasan dengan Propinsi Jawa Tengah, Sebelah timur kecamatan berbatasan dengan Kecamatan Cangkringan, Sebelah selatan kecamatan berbatasan dengan Kecamatan Ngemplak dan Kecamatan Ngaglik, Sebelah barat kecamatan berbatasan dengan Kecamatan Ngemplak

2. Kondisi Fisik Daerah Penelitian

a. Kondisi Geomorfologis

Wilayah lereng Merapi terdiri atas: Kerucut Vulkan (Volcanic cone), lereng vulkan (Volcanic Slope: upper, middle, lower), lerengkaki vulkan (volcanic foot slope), dataran fluvial kaki vulkan (fluvio volcanic foot plain) dan dataran fluvial vulkanik (fluvio volcanic plain). Di wilayah penelitian, ada tiga satuan geomorfik, yaitu:

1) Lereng Atas, kerucut dan kawah Gunungapi Merapi yang mempunyai lembah dalam, lereng curam, topografi bergelombang hingga berbukit yang menempati ketinggian lebih besar dari 1.000 meter hingga puncak Gunungapi Merapi (2.968 m dpal).

2) Lereng Tengah Gunungapi Merapi yang mempunyai topografi berombak hingga bergelombang, dengan lembah-lembah sungai yang paralel adalah merupakan zona munculnya mata air. Kemiringan lereng landai sampai miring ke arah selatan sehingga air permukaan dan air tanah sesuai dengan arah kemiringan lerengnya. Ketinggian tempat bervariasi antara 500 meter sampai 1000 meter di atas permukaan air laut.

3) Lereng Bawah Gunungapi Merapi yang mempunyai topografi hampir datar sampai berombak, kemiringan lereng kurang dari $5 \%$ dan mempunyai lembah yang relatif panjang. Ketinggian antara 100 meter sampai 500 meter di atas permukaan air laut.

b. Kondisi Geologis 
Kondisi geologis daerah penelitian dapat diklasifikasi-kan dalam tiga kelompok yaitu:

1) Endapan Permukaan atau Longsoran (Surficial Deposits)

Endapan permukaan ini berupa endapan alluvial dan fluvial yang terdiri atas material pasir dan kerikil serta hasil rombakan dari endapan Merapi muda dan tua yang berupa tuffa dan breksi yang terkonsolidasi lemah hingga kuat.

2) Endapan Merapi Muda (Young Merapi Voliano)

Endapan Merapi muda terdiri dari aliran lava piroksen, endapan jatuhan piroklastik, guguran lava, endapan aliran piroklastik muda Merapi, dan endapan lahar muda Merapi. Materialnya tersusun dari ash, lapili, lempung, pasir hingga kerikil yang terkonsolidasi lemah hingga kuat.

3) Endapan Merapi Tua (Old Merapi Volcano)

Endapan merapi tua terdiri atas aliran piroklastik tua Merapi, endapan lahar tua Merapi, aliran lava andesit. Materialnya terdiri dari fragmen kerikil hingga bongkah yang terkonsolidasi kuat dan adanya batuan intrusif.

c. Topografi

Wilayah Kecaniatan Ngemplak mempunyai ketinggian antara $200 m$ - 650m di atas permukaan laut. Secara umum Kecamatan Ngemplak merupakan wilayah yang agak miring dengan slope sekitar 3 5\%. Wilayah Kecamatan Pakem mempunyai ketinggian antara $400 \mathrm{~m}-2000 \mathrm{~m}$ di atas permukaan air laut, dan luas total $4.384 \mathrm{Ha}$. Bentuk Wilayah Kecamatan Pakem bervariasi yaitu wilayah dataran sampai berombak, wilayah berombak sampai berbukit, dan wilayah berbukit sampai bergunung.

d. Jenis Tanah

Berdasarkan Peta Jenis Tanah Penyusunan Rencana Tata guna Tanah Kabupaten Sleman Tahun 1989/1990 dari Lembaga Penelitian Tanah DIY dengan skala 1 : 50.000 jenis tanah yang terdapat di Kecamatan Ngemplak termasuk jenis tanah Regosol Kelabu. Tanah Regosol Kelabu ini faktor pembentuknya terdiri dari bahan induk berupa kompleks abu, pasir vulkan dan batuan intermedier. Tanah regosol mempunyai corak yaitu beriekstur pasir dan struktur tanpa atau berbutir tunggal, sedangkan sifatnya yaitu 
kemasaman beraneka, zat organik rendah, kejenuhan basa aneka, daya adsorpsi rendah, unsur hara aneka, dan permeabilitas tinggi.

Jenis tanah di Kecamatan Pakem berasal dari batuan dasar vulkanik yang mempunyai sifat fisik yaitu mudah meloloskan air sehingga sangat potensial untuk meresapkan air hujan ke dalam tanah. Jenis tanah di Kecamatan Pakem menurut peta jenis tanah Kabupaten Sleman tahun 1989/1990 termasuk ke dalam kelompok regosol coklat keabuan serta regosol komplek abu-tuffa dan batuan vulkan intermedier yang tergolong muda. Adapun tanah regosol mempunyai sifat fisik dengan tekstur pasiran, granulair dengan butir tunggal, lepas-lepas, permeabel, dan berwarna coklat kelabu.

e. Kemiringan Lahan

Kecamatan Pakem terletak pada lereng atas dan lereng tengah dari gunungapi Merapi. Pada daerah penelitian mempunyai remiringan lahan sebagaimana tertera pada tabel 1 berikut.

Tabel 1.. Persentase Kemiringan Lahan Kecamatan Pakem

\begin{tabular}{|c|c|}
\hline Kemiringan Lahan & Luas (Ha) \\
\hline $0-2 \%$ & 0 \\
\hline $2-15 \%$ & 2.445 \\
\hline $15-40 \%$ & 1.201 \\
\hline$>40 \%$ & 738 \\
\hline Jurnlah & 4.384 \\
\hline
\end{tabular}

Sumber: Atlas, Agenda, Aturan Kabupaten Sleman Th. 2003

Tabel di atas menunjukkan bahwa $55,77 \%$ dari total luas wilayah Kecamatan Pakem berada pada kemiringan Iahan antara 2 $15 \%$, sedangkan $27,39 \%$ berada pada kemiringan lahan antara 15 $40 \%$ yaitu di sebelah utara sebagian Desa Hargobinangun dan Desa Purwobinangun. Masing masing ketiga desa yang lainnya yaitu Desa Pakembinangun, Desa Candibinangun, dan Harjobinangun berada pada kemiringan lahan kategori datar hingga landai atau antara $2-15 \%$. Untuk kemiringan lebih dari $40 \%$ seluas $738 \mathrm{Ha}$ atau sekitar $16,84 \%$ yaitu hanya di sekitar vulkan aktif Merapi atau masuk terituri Desa Hargobinangun.

f. Iklim

Penggolongan tipe iklim di daerah penelitian didasarkan pada klasifikasi iklim Köppen, sedangkan penggolongan curah 
hujan menurut Schmidt Ferguson. Oleh karena itu akan diuraikan di bagian ini mengenai kedua hal tersebut.

(1). Iklim Wilayah Ngemplak

Untuk mengetahui besarnya curah hujan di wilayah Kecamatan Ngemplak dapat dilihat pada uraian berikut, berdasar data curah hujan selama sepuluh tahun sejak 1996 hingga 2005.

Curah hujan rata-rata Kecamatan Ngemplak adalah 2.840 $\mathrm{mm}$ dengan rata-rata hari hujan adalah 101 hari per tahun. Bulan basah (curah hujan melebihi $100 \mathrm{~mm}$ ) rata-rata terjadi pada bulan Oktober hingga Mei, dengan bulan terbasah jatuh pada bulan Februari yaitu 462,6 mm. Bulan kering (curah hujan kurang dari 60 $\mathrm{mm}$ ) rata-rata terjadi pada bulan Juni hingga September, dengan bulan terkering jatuh pada bulan September yaitu hanya $12 \mathrm{~mm}$. Curah hujan minimum sebesar 1.763 mm terjadi pada tahun 1997 dengan hanya 65 hari hujan saja, sedangkan curah hujan maksimum sebesar $4.611 \mathrm{~mm}$ terjadi pada tahun 1998 dengan 156 hari hujan. Rata-rata bulan basah adalah 7,4 bulan setiap tahun, dan rata-rata bulan lembab adalah 1,3 bulan, sedangkan rata-rata bulan kering adalah 3,3 bulan setiap tahun.

Berdasarkan data curah hujan tersebut Kecamatan Ngemplak termasuk dalam:

$$
Q=\frac{\text { Rata-rata jumlah bulan kering }}{\text { Rata-rata jumlah bulan basah }} \times 100 \%
$$

Semakin besar nilai Q semakin kering suatu daerah, dan semakin kecil nilai Q maka semakin basah suatu daerah. Besarnya nilai Q di wilayah Kecamatan Ngemplak adalah:

$$
\mathrm{Q}=\frac{3,3}{7,4} \times 100 \%=44,56 \%
$$

Dalam hal suhu udara, wilayah Kecamatan Ngemplak terletak pada ketinggian 350 - $1.073 \mathrm{~m}$ dpal, maka suhu udara dapat dihitung dengan menggunakan formula Braak, yaitu:

$$
\mathrm{T}=26,3-0,6 \mathrm{H}
$$


Dengan keterangan sebagai berikut:

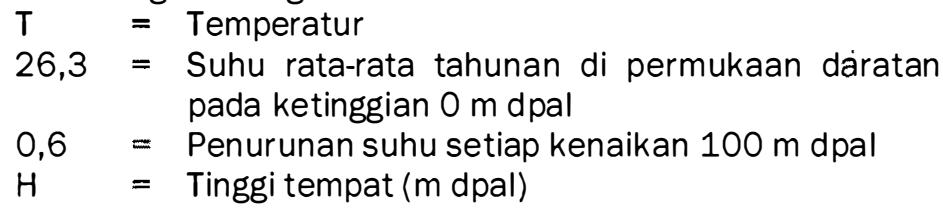

Berdasarkan formula di atas, maka Kecamatan Ngemplak yang terletak di ketinggian antara 350 - $1.073 \mathrm{~m}$ dpal, dapat dicari temperatur rata-rata tahunannya yaitu:

Rata-rata temperatur pada ketinggian $350 \mathrm{~m}$ dpal ialah:

$\mathrm{T}=26,3^{\circ} \mathrm{C}-0,6^{\circ} \mathrm{C} \times 3,50$

$$
\begin{aligned}
& =26,3^{\circ} \mathrm{C}-2,1^{\circ} \mathrm{C} \\
& =24,2^{\circ} \mathrm{C}
\end{aligned}
$$

Rata-rata temperatur pada ketinggian $1.073 \mathrm{~m}$ dpal:

$\mathrm{T}=26,3^{\circ} \mathrm{C}-0,6^{\circ} \mathrm{C} \times 10,73$

$=26,3^{\circ} \mathrm{C}-6,4^{\circ} \mathrm{C}$

$=19,9^{\circ} \mathrm{C}$

Dari hasil perhitungan tersebut, maka secara keseluruhan Kecamatan Ngemplak mempunyai temperatur tahunan rata-rata berkisar antara $19,9^{\circ} \mathrm{C}-24,2^{\circ} \mathrm{C}$.

Berdasarkan pembagian tipe iklim, wilayah Kecamatan Ngemplak termasuk ke dalam tipe iklim A, dikarenakan kecamatan Ngemplak memiliki suhu bulan terdingin lebih dari $18^{\circ} \mathrm{C}$ yaitu antara $19,9^{\circ} \mathrm{C}$ sampai $24,2^{\circ} \mathrm{C}$.

(2). Iklim Wilayah Pakem

Curah hujan rata-rata Kecamatan Pakem adalah $2.940 \mathrm{~mm}$, dengan rata-rata hari hujan yaitu 120 hari per tahun. Bulan basah (curah hujan lebih dari $100 \mathrm{~mm}$ ) rata - rata terjadi pada bulan Oktober hingga Mei, dengan bulan terbasah jatuh pada bulan Februari yaitu sebesar 599,8 $\mathrm{mm}$. Untuk bulan kering rata-rata terjadi antara bulan Juni hingga September, dengan bulan terkering jatuh pada bulan September yaitu hanya sebesar $8,6 \mathrm{~mm}$. Curah hujan maksimum tahunan terjadi pada tahun 1998 yaitu sebesar $4983 \mathrm{rmm}$, dengan banyak hari hujan adalah 193 hari setahun. Untuk rata- rata bulan basah adalah 7 bulan per tahun, rata-rata bulan lembab 0,7 dan terakhir rata-rata bulan kering adalah 4,3 bulan per tahun. Kecamatan Pakem termasuk ke dalam tipe $D$, yaitu dengan nilai $Q=61,42 \%$. 
Dalam hal suhu udara, wilayah Kecamatan Pakem terletak pada ketinggian 400m - 2500m dpal, sehingga dapat diketahui temperatur Kecamatan Pakem dengan perhitungan sebagai berikut:

$$
\begin{aligned}
\mathrm{T} & =26,3^{\circ} \mathrm{C}-0,6^{\circ} \mathrm{C} \times \mathrm{H} \\
& =26,3^{\circ} \mathrm{C}-0,6^{\circ} \mathrm{C} \times 4,00 \\
& =26,3^{\circ} \mathrm{C}-2,4 \\
& =23,9^{\circ} \mathrm{C}
\end{aligned}
$$

Temperatur wilayah Kecamatan Pakem pada ketinggian $400 \mathrm{~m}$ dpal sebesar $23,9^{\circ} \mathrm{C}$. Temperatur rerata wilayah Kialiurang dengan ketinggian $900 \mathrm{~m}$ dpal seperti berikut:

$$
\begin{aligned}
\mathrm{T} & =26,3^{\circ} \mathrm{C}-0,6^{\circ} \mathrm{C} \times \mathrm{H} \\
& =26,3^{\circ} \mathrm{C}-0,6^{\circ} \mathrm{C} \times 9,00 \\
& =26,3^{\circ} \mathrm{C}-5,4^{\circ} \mathrm{C} \\
& =20,9^{\circ} \mathrm{C}
\end{aligned}
$$

Sedangkan wilayah Pakem atas yang merupakan lereng Merapi atas, temperatur pada ketinggian $2.500 \mathrm{~m}$ dpal adalah sebagai berikut:

$$
\begin{aligned}
\mathrm{T} & =26,3^{\circ} \mathrm{C}-0,6^{\circ} \mathrm{C} \cdot \mathrm{H} \\
& =26,3^{\circ} \mathrm{C}-0,6^{\circ} \mathrm{C} \times 25,00 \\
& =26,3^{\circ} \mathrm{C}-15 \\
& =11,3^{\circ} \mathrm{C}
\end{aligned}
$$

Secara keseluruhan wilayah Kecamatan Pakem mempunyai temperatur tahunan rata-rata berkisar antara $11,3^{\circ} \mathrm{C}-23,9^{\circ} \mathrm{C}$.

Di wilayah penelitian, curah hujan tergolong sangat tinggi. Di wilayah Pakem bahkan mencapai $2.940 \mathrm{~mm}$, lebih tinß̧gi daripada wilayah Ngemplak, yaitu 2.840 mm. Curah hujan puncak terjacii bulan Februari. Pada pertengahan bulan Januari dan Februari inilah mulai tampak adanya runoff, hingga parit-parit mulai dialiri air hingga berakhir pada bulan Mei, kecuali beberapa parit dan kali yang di daerah hulu berupa mata air.

g. Kondisi Hidrologis

Air merupakan kebutuhan pokok bagi pertumbuhan tanaman khususnya tanaman-tanaman keras hutan terkait dengan daerah peresapan air. Wilayah Kecamatan Ngemplak dialirı oleh empat buah sungai besar yaitu Sungai Bedog, Sungai Klengur,, Sungai Sempur, dan Sungai Kali Adem. Keempat sungai tersebut mengalir sesuai dengan topografinya yang miring atau semakin 
rendah dari utara ke selatan. Daerah penelitian dikontrol oleh Sistem Akifer Merapi (SAM) yang tersusun atas formasi Yogyakarta pada bagian atas dan formasi Sleman pada bagian bawah. Sungaisungai di Kecamatan Ngemplak sebagian besar digunakan untuk pertanian oleh penduduk setempat. Hal tersebut dibuktikan dengan adanya 235 dam atau bendung, 1 buah waduk seluas 1 hektar, dan $10 \mathrm{~km}$ saluran irigasi primer dan sekunder.

Air tanah pada umumnya berasal dari air hujan yang masuk dan meresap ke dalam tanah melalui proses infiltrasi. Jumlah air hujan yang masuk ke dalam tanah menjadi air tanah tergantung pada kondisi yang menyebabkan air hujan dapat mempunyai kesempatan dan mampu bertahan lama pada pada permukaan tanah namun tidak mengalami suatu aliran sehingga air hujan tersebut dapat meresap lebih banyak dan dapat menjadi air tanah dalam jumlah yang banyak pula. Kondisi yang cukup untuk mendukung peresapan air hujan menjadi air tanah adalah adanya vegetasi, lereng yang datar dan faktor jenis tanahnya.

Air tanah dikontrol oleh Sistem Akifer Merapi (SAM). Sistem Akifer Merapi ini mempunyai topografi yang miring ke selatan sesuai dengan topografinya yang semakin rendah dari utara menuju ke selatan.

Kecamatan Pakem memiliki empat daerah aliran sungai, antara lain Sungai Boyong, Sungai Tangkil, Sungai Pelang, dan yang terakhir adalah Sungai Srumbung. Selain sungai di Kecamatan Pakem juga terdapat satu buah air terjun dengan lebar minimal $2 \mathrm{~m}$ dan tinggi kurang lebih $10 \mathrm{~m}$, tepatnya di kawasan wisata Kaliurang yang debit airnya semakin kecil terutama bila musim kemarau tiba. Sungai-sungai di Kecamatan Pakem pada umumnya digunakan untuk pengairan pertanian atau perikanan. Kebutuhan air bersih pada umumnya masyarakat menggunakan air tanah (sumur) atau PDAM. Kecamatan Pakem juga memiliki 24 buah dam dan 5 tanggul banjir untuk menanggulangl terjadlnya aliran alr yang bercampur material vulkanik pada saat terjadi bencana letusan vulkan Merapi.

h. Kondlsi Demografis

(1.). Pertumbuhan Penduduk Ngemplak 
Jumlah penduduk Kecamatan Ngemplak mengalami peningkatan dari tahun. ke tahun, seperti wilayah kecamatan lain di Kabupaten Sleman pada umumnya. Di kecamatan ini telah bermunculan permukiman perumahan yang ditangani oleh developer maupun masyarakat secara mandiri. Disamping juga banyak perkantoran dan kampus baru. Contohnya Perumahan Pamungkas, Perumahan IDI, Perkantoran kompleks Sentral Pendidikan BRI, kampus UII beserta kampus AKPER, permukiman baru di sekitar kampus, pertokoan, minimarket, dan sebagainya.

Pada tahun 1990 jumlah penduduk Kecamatan Ngemplak sebesar 26.447 orang, kemudian tahun 2000 terjadi peningkatan sebesar 2.647 jiwa atau total menjadi 29.124 jiwa. (2). Kepadatan penduduk

Kepadatan penduduk geografis menunjukkan jumlah penduduk pada suatu daerah setiap kilometer persegi. Hal tersebut juga digunakan untuk memperkuat asumsi bahwa semakin padat jumlah penduduk di suatu daerah akan semakin memperbesar luas penggunaan lahan baik untuk permukiman maupun prasarana dan sarana pendukungnya. Kepadatan penduduk masing-masing Desa Kecamatan Ngemplak disajikan dalam Tabel 2.

Dari Tabel 2 terlihat bahwa kepadatan penduduk Kecamatan Ngemplak mengalami peningkatan. Pada tahun 2001 kepadatan penduduk Kecamatan Ngemplak adalah 764 jiwa per kilometer persegi. Sedangkan tahun 2004 telah mengalami peningkatan menjadi 788 jiwa per kilometer persegi. Jumlah tersebut diperoleh dari total jumlah penduduk dibagi luas wilayahnya. Desa dengan kepadatan penduduk tertinggi ialah Bangunkerto mencapai $1.200 \mathrm{jiwa} / \mathrm{km}^{2}$ di tahun 2001 dan pada tahun 2004 menjadi 1.235 jiwa $/ \mathrm{km}^{2}$ atau mengalami kenaikan sebanyak 35 jiwa dari total luas wilayah. 
Tabel 2. Kepadatan Penduduk Menurut Desa Di Kecamatan Ngemplak Tahun 2001 dan 2004

\begin{tabular}{|l|c|c|c|c|c|}
\hline \multirow{2}{*}{\multicolumn{1}{c|}{ Desa }} & \multirow{2}{*}{$\begin{array}{c}\text { Luas } \\
\text { Wilayah } \\
\left(\mathrm{kmi}^{2}\right)\end{array}$} & \multicolumn{2}{c|}{$\begin{array}{c}\text { Jumlah } \\
\text { Penduduk }\end{array}$} & \multicolumn{2}{c|}{$\begin{array}{c}\text { Kepadatan } \\
\left(\mathrm{Jiwa} / \mathrm{km}^{2}\right)\end{array}$} \\
\cline { 3 - 6 } & 2001 & 2004 & 2001 & 2004 \\
\hline Umbulmartani & 6,03 & 8.439 & 8.684 & 1.200 & 1.235 \\
\hline Bimomartani & 3,41 & 4.719 & 8.974 & 1.177 & 1.211 \\
\hline Widodomartani & 3,07 & 3.364 & 3.582 & 1.063 & 1.180 \\
\hline Wedomartani & 7,58 & 8.414 & 8.656 & 1.240 & 1.362 \\
\hline Sindumartani & 3,02 & 3031 & 3.132 & 1004 & 1.112 \\
\hline Jumlah & & & & & \\
\hline
\end{tabular}

Sumber: Kecamatan Ngemplak dalam Angka Tahun 2001 dan 2005 (BPS)

(3). Pertumbuhan Penduduk Pakem

Kecamatan Pakem mengalami peningkatan jumlah penduduk dalam kurun waktu 15 tahun terakhir. Menurut Atlas, Agenda, Aturan Kabupaten Sleman di akhir tahun 1980 jumlah penduduk Kecamatan Pakem sebesar 26.762 jiwa. Tahun 2000 telah menjadi 28.026 jiwa. Pertumbuhan penduduk di Kecamatan Dakem di tahun 2000 mencapai 1.161 jiwa dalam kurun waktu 10 tahun atau rata-rata per tahun mengalami peningkatan sebesar 116,1 jiwa.

Wilayah Kecamatan Pakem memiliki objek wisata yang cukup dikenal yaitu kawasan wisata Kaliurang. Dengan adanya objek pariwisata tersebut semakin mendorong masyarakatnya untuk menyediakan berbagai sarana maupun prasarana pendukung, sehingga memperkuat asumsi dengan adanya pembangunan sarana prasarana akan semakin memperbesar penggunaan lahan non pertanian dan kehutanan.

Berikut ini disajikan data terbaru jumlah dan kepadatan penduduk pada masing-masing desa di Kecamatan Pakem antara tahun 2001 dan tahun 2004. 
Tabel 3. Jumlah Penduduk Masing-Masing Desa Di Kecamatan Pakem Tahun 2001 dan 2004.

\begin{tabular}{|l|c|c|c|}
\hline \multirow{2}{*}{ Desa } & \multicolumn{2}{c|}{$\begin{array}{c}\text { Jumlah } \\
\text { Penduduk }\end{array}$} & $\begin{array}{c}\text { Laju } \\
\text { Pertumbuhan } \\
\text { Penduduk (jiwa) }\end{array}$ \\
\cline { 2 - 3 } & 2001 & 2004 & \\
\hline Purwobinangun & 8.322 & 8.759 & 437 \\
\hline Candibinangun & 4.792 & 4.908 & 116 \\
\hline Harjobinangun & 5.165 & 5.342 & 177 \\
\hline Pakembinangun & 5.226 & 6.029 & 803 \\
\hline Hargobinangun & 7.100 & 7.216 & 116 \\
\hline Jumlah & 30.605 & 32.254 & 1.649 \\
\hline
\end{tabular}

Sumber: Kecamatan Pakem dalam Angka Tahun 2001 dar, 2005 (BPS)

Dari tabel 3 terlihat bahwa Desa Purwobinangun menempati urutan pertama desa dengan jumlah penduduk terbesar yaitu sebanyak 8.759 jiwa di akhir tahun 2004 dengan pertumbuhan penduduk selama kurun waktu 3 tahun terakhir sebanyak 437 jiwa. Kemudian di urutan selanjutnya Desa Hargobinangun dengan jumlah penduduk sebanyak 7.216 jiwa dan angka pertumbuhan penduduk 3 tahun terakhir sebanyak 116 jiwa. Hal ini dikarenakan kedua desa tersebut cukup luas yakni lebih dari 1000 ha, selain it $d$ desa Hargobinangun mencakup lokasi wisata Kaliurang, sehingga arus kedatangan wisatawan maupun masyarakat yang akhirnya menetap menjadi penduduk cukup tinggi. Namun jika dilihat dari angka laju pertumbuhan penduduk Desa Pakembinangun yang paling tinggi yaitu mencapai 803 jiwa dalam 3 tahun terakhir. Hal tersebut dimungkinkan karena banyaknya fasilitas-fasilitas umum yang tersedia, antara lain kantor-kantor pemerintahan, Bank, Pegadaian, Sekolah, serta Pasar. Selain itu aksesibilitas Desa Pakembinangun relatif dekat menuju ke salah satu perguruan tinggi swasta terkemuka di Yogyakarta, sehingga semakin memicu pertumbuhan penduduk.

\section{Pengetahuan Manfaat Sumur Resapan Air Hujan}

Berdasarkan hasil wawancara diperoleh pengetahuan manfaat sumur resapan air hujan dari masyarakat seperti tabel 4 berikut. 
Tabel 4. Pengetahuan Manfaat Sumur Resapan Air Hujan .Untuk Menghindari Banjir

\begin{tabular}{|c|l|c|c|}
\hline No. & Tingkat pengetahuan & Responden & $\%$ \\
\hline 1. & Tahu & 23 & 82,15 \\
\hline 2. & Tidak tahu & 5 & 17,85 \\
\hline
\end{tabular}

Berdasarkan data primer pada tabel di atas diketahui bahwa sebagian responden tahu manfaat sumur resapan air hujan, yaitu sebanyak $82,15 \%$. Hanya $17,85 \%$ responden yang tidak tahu manfaat sumur resapar., meskipun demikian hanya tahu manfaatnya untuk menghindari banjir. Dalam ha! pengetahuan masyarakat untuk konservasi tanah, menjadi berbanding terbalik. Maksudnya jumlah masyarakat yang tahu manfaatnya untuk konservasi air tanah lebih kecil daripada yang tidak tahu, yaitu 39,28\% (Lihat tabel 5).

Tabel 5. Pengetahuaiı Manfaat Sumur Resapan Air Hujan Untuk Konservasi Air Tanah

\begin{tabular}{|c|l|c|c|}
\hline No. & Tingkat pengetahuan & Responden & $\%$ \\
\hline 1. & Tahu & 11 & 39,28 \\
\hline 2. & Tidak tahu & 17 & 60,72 \\
\hline
\end{tabular}

\section{Kepemilikan Sumur Resapan Air Hujan}

Sampel penduduk di dua kecamatan wilayah penelitian menunjukkan bahwa sebagian besar atau rata-rata responden tidak memiliki resapan air hujan $(89,29 \%)$. Sebagian kecil responden yang memiliki resapan air hujan $(10,71 \%)$ ditemukan sebagian besar pada perumahan yang berkembang secara swadaya (Lihat tabel 6).

Tabel 6. Kepemilikan Sumur Resapan Air Hujan

\begin{tabular}{|c|l|c|c|}
\hline No. & \multicolumn{1}{|c|}{ Kepemilikan } & Responden & $\%$ \\
\hline 1. & Memiliki & 3 & 10,71 \\
\hline 2. & Tidak memiliki & 25 & 89,29 \\
\hline
\end{tabular}

Perumahan yang dibangun oleh perusahaan pengembang, ironisnya tidak memiliki sumur resapan air hujan. Perumahan Pamungkas, Perumahan IDI, Perumahan BRI adalah contoh perumahan yang dibangun oleh perusahaan developer tetapi hanya menggunakan saluran drainase untuk membuang limpahan air hujan hingga masuk ke kali terdekat. Sebaliknya kompleks perumahan kecil yang dibangun sendiri secara 
mandiri seperti Perumahan Kavling UII, warga langsung membangun sumur resapan air hujan. Hal itu dilakukan di samping lebih mudah membuang limpahan air hujan, juga biayanya lebih murah dibandingkan bila harus membangun saluran drainase. Namun demikian dari hasil wawancara ke penduduk dan tokoh masyarakat, terjadinya pembangunan sumur resapan bukan karena kesadaran pentingnya sumur resapan urituk menghindari timbulnya genangan air atau konservasi air tanah. Hal itu dilakukan karena belum adanya sarana saluran drainase air hujan.

Masyarakat responden yang tertarik akan membangun resapan air hujan juga tidak banyak. Sebanyak $67,86 \%$ responden menyatakan tidak akan membangun sumur resapan air hujan, hanya $7,14 \%$ merencanakan membangun sumur resapan air hujan, sedangkan sisanya tidak akan membangun sumur resapan air hujan (Lihat tabel 7).

Tabel 7. Rencana Pembangunan Sumur Resapan Air Hujan

\begin{tabular}{|c|l|c|c|}
\hline No. & Tindakan Mendatang & Responden & $\%$ \\
\hline 1. & Merencanakan & 2 & 7,14 \\
\hline 2. & Tidak & 19 & 67,86 \\
\hline 3. & Tidak tahu & 7 & 25,00 \\
\hline
\end{tabular}

Sebagian besar responden mengetahui manfaat sumur resapan air hujan untuk menghindari banjir sebanyak $82,15 \%$. Namun sebagian besar responden tidak mengetahui bahwa sumur resapan air hujan bermanfuat untuk konservasi air tanah, yaitu sebanyak 60,72\%. Hanya 10,71\% responden memiliki sumur resapan air hujan. Meskipun demikian alasannya karena menghindari banjir, bukan karena alasan konservasi air tanah. Untuk kaitannya rencana pembangunan sumur resapan air hujan, sebagian besar responden tidak akan membangun $(67,86 \%)$, dengan alasan sudah membangun dan sudah ada saluran drainase. Hanya $7,14 \%$ yang merencanakan membangun sumur resapan air hujan dengan alasan selalu ada genangan air di seputar rumah bila ada hujan deras. Selebihnya (25\%) belum atau tidak tahu, akan membangun atau tidak.

Wilayah Pakem dan Ngemplak masih berupa lahan yang potensial untuk wilayah resapan air hujan, untuk saat ini. Wilayah resapan air hujan sangat dipengaruhi oleh keberadaan hutan, kelerengan lahan yang relatif tidak terlalu curam, dan jenis tanah yang relatif porus. Di wilayah Kecamatan Pakem bagian atas merupakan lahan yang relatif curam, yaitu wilayah sekitar Kaliurang ke arah puncak Gunung Merapi. Namun walaupun lahannya relatif curam, masih banyak hutannya, kecuali wilayah 
dekat puncak yang telah terbakar oleh erupsi Merapi. Wilayah Kaliurang ke arah Selatan berupa lahan dengan lereng sedang, tanah regosol muda yang porus, dan perladangan. Sebagian kecil berupa persawahan. Dalam arti, berdasarkan peta penggunaan lahan yang dibuat berdasar data tahun 2003, hanya sebagian kecil saja yang berupa wilayah permukiman baru, sebagian besar berupa ladang dan berupa tanah regosol, bahkan regosol muda. Hujan yang jatuh di awal musim penghujan memerlukan waktu satu bulan untuk membuat tanah menjadi jenuh air. Selama satu bulan itu pula belum ada limpasán air (runoff) yang berarti.

Ferkembangan permukiman di dua wilayah kecamatan, terutama Kecamatan Ngemplak dan Pakem bagian bawah dapat berakibat menurunnya wilayah resapan air hujan. Sejalan dengan proses perkembangan wilayah, degradasi lahan (erosi, sedimentasi), limpasan air permukaan (run-oif), banjir, kelangkaan sumber daya air menjadi semakin meningkat (Sudarmaji, 1996). Sikap masyarakat yang belum terlalu peduli, dan kemauan pemerintah yang kurang aktif dalam menyosialisasikan Perda tentang kewajiban pembangunan sumur resapan air hujan dapat cepat memicu percepatan krisis air bersih maupun banjir bandang. Meskipun demikian sejak sekarang harus sudah ada sangsi peraturan tegas dalam kaitan dengan kewajiban masyarakat membangun sumur resapan air hujan bagi setiap penduduk yang membangun rumah.

\section{Penutup}

Berdasarkan analisis data dapat disimpulkan sebagai berikut:

1. Sebagian besar masyarakat Sleman yang ada di Kecamatan Pakem dan Ngemplak yang menjadi responden sudah tahu manfaat sumur resapan air hujan untuk menghindari banjir, walaupun sebagian besar tidak tahu manfaatnya untuk konservasi air tanah.

2. Sebagian besar responden tidak akan membangun sumur resapan air hujan.

3. Ketidakpedulian masyarakat membangun sumur resapan air hujan karena sebagian besar lingkungan permukimannya sudah tersedia saluran drainase.

4. Kesimpulan umum masalah resapan air hujan semakin memprihatinkan, karena semakin sedikitnya luas resapan air hujan. 
I| Studi Kepedulian Masyarakat Sleman Membangun Sumur Resapan Air Hujan

\section{Daftar Pustaka}

Asdak, Chay. 1995. Hidrologi Daerah Aliran Sungai. Yogyakarta: Gadjah Mada University Press.

Keppres No 32 tahun 1990 tentang Pengelolaan Kawasan Lindung.

Kodoatie, Robert. 1996. Kajian Undang-undang Sumberdaya Air. Yogyakarta: Penerbit Andi.

Sudarmaji. 1996. Pengelolaan Sumberdaya Air: Diktat Kuliah. Yogyakarta: Fakultas Geografi UGM. 